\title{
Switch from epoetin to darbepoetin alfa in hemodialysis: dose equivalence and hemoglobin stability
}

This article was published in the following Dove Press journal: International Journal of Nephrology and Renovascular Disease 9 October 2014

Number of times this article has been viewed

\author{
Javier Arrieta' \\ Iñigo Moina' \\ José Molina ${ }^{2}$ \\ Isabel Gallardo ${ }^{3}$ \\ María Luisa Muñiz ${ }^{4}$ \\ Carmen Robledo 5 \\ Oscar García ${ }^{5}$ \\ Fernando Vidaur ${ }^{6}$ \\ Rosa Inés Muñoz ${ }^{3}$ \\ Izaskun Iribar ${ }^{7}$ \\ Román Aguirre ${ }^{7}$ \\ Antonio Maza ${ }^{8}$
}

'Hospital de Basurto, Bilbao, ${ }^{2}$ Hospital de Donostia, Donostia-San Sebastián, ${ }^{3}$ Hospital de Galdakao-Usansolo, Galdakao, ${ }^{4}$ Hospital de Cruces, Baracaldo, ${ }^{5}$ Hospital de Santiago, Vitoria-Gasteiz, ${ }^{6}$ Policlínica de Guipúzcoa, Donostia-San Sebastián, ${ }^{7}$ Hemobesa Clinica Virgen Blanca, Bilbao, ${ }^{8}$ Dialbilbo, Bilbao, Spain
Correspondence: Javier Arrieta Nephrology Service, Hospital Universitario Basurto, Avda de Montevideo 18, ES - 480I3 Bilbao, Spain Tel +3494 4006034 Fax +3494 4006395

Email javier.arrietalezama@osakidetza.net
Aim: The objective of the study reported here was to describe dose equivalence and hemoglobin $\mathrm{Hb}$ ) stability in a cohort of unselected hemodialysis patients who were switched simultaneously from epoetin alfa to darbepoetin alfa.

Methods: This was a multicenter, observational, retrospective study in patients aged $\geq 18$ years who switched from intravenous (IV) epoetin alfa to IV darbepoetin alfa in October 2007 (Month 0) and continued on hemodialysis for at least 24 months. The dose was adjusted to maintain $\mathrm{Hb}$ within $1.0 \mathrm{~g} / \mathrm{dL}$ of baseline.

Results: We included 125 patients (59.7\% male, mean [standard deviation (SD)] age 70.4 [13.4] years). No significant changes were observed in Hb levels (mean [SD] 11.9 [1.3] g/dL, 12.0 [1.5], 12.0 [1.5], and 12.0 [1.7] at Months -12, 0, 12 and 24, respectively, $P=0.409)$. After conversion, the erythropoiesis-stimulating agent (ESA) dose decreased significantly $(P<0.0001)$, with an annual mean of 174.7 (88.7) international units (IU)/kg/week for epoetin versus 95.7 (43.4) (first year) and 91.4 (42.7) IU/kg/week (second year) for darbepoetin (65\% and 64\% reduction, respectively). The ESA resistance index decreased from 15.1 (8.5) IU/kg/week/g/dL with epoetin to 8.1 (3.9) (first year) and 7.9 (4.0) (second year) with darbepoetin $(P<0.0001)$. The conversion rate was $354: 1$ in patients requiring high ( $>200 \mathrm{IU} / \mathrm{kg} /$ week) doses of epoetin and 291:1 in patients requiring low doses.

Conclusion: In patients on hemodialysis receiving ESAs, conversion from epoetin alfa to darbepoetin alfa was associated with an approximate and persistent reduction of $65 \%$ of the required dose. To maintain $\mathrm{Hb}$ stability, a conversion rate of $300: 1$ seems to be appropriate for most patients receiving low doses of epoetin alfa ( $\leq 200 \mathrm{IU} / \mathrm{kg} /$ week), while 350:1 would be better for patients receiving higher doses.

Keywords: chronic kidney disease, darbepoetin alfa, dose equivalence, epoetin alfa, hemodialysis, hemoglobin

\section{Introduction}

Anemia is the complication that has the greatest impact on perceived quality of life in patients with chronic kidney disease on hemodialysis. Therapy with erythropoiesisstimulating agents (ESAs) significantly reduces the need for transfusions, hospital admissions, and overall mortality. ${ }^{1-4}$

"Epoetin alfa" is a recombinant erythropoietin with the same amino acid sequence as human erythropoietin (EPO). ${ }^{5}$ Subcutaneous (SC) administration has a higher therapeutic effect than intravenous (IV) administration, because the effect of epoetin alfa on erythropoiesis depends more on peak levels than on through levels. ${ }^{5,6}$ However, it is almost exclusively used intravenously in hemodialysis patients to avoid the production of anti-EPO antibodies. ${ }^{2}$ 
In comparison to epoetin alfa, darbepoetin alfa contains an increased amount of sialic acid-containing carbohydrate chains. $^{7-9}$ It shows a much longer elimination half-life than epoetin alfa, with prolonged erythropoietic effect. ${ }^{10-15}$ Another peculiarity is the equivalence of IV and SC dosing requirements. ${ }^{1,10,16}$ The initially recommended conversion factor was 200 international units (IU) of epoetin alfa per $1 \mu \mathrm{g}$ of darbepoetin alfa. ${ }^{12}$ However, several studies have found that, after switching from epoetin alfa to darbepoetin alfa, a mean dose reduction of between $17 \%$ and $39 \%$ is required to maintain stable hemoglobin $(\mathrm{Hb})$ levels. ${ }^{3,17-23}$ Further, there is wide inter-patient variability in the conversion rate..$^{23,24}$ Despite the fact that label instructions remain unchanged, all these observations have resulted in nephrologists using a conversion rate of 250:1 in clinical practice. ${ }^{20-23}$

Due to a decision of the Central Purchasing Center of the Basque Health Service, Spain, the type of ESA was changed simultaneously for all hemodialysis patients in the area. The present study aimed to assess the effect on $\mathrm{Hb}$ levels and dose requirements of switching from epoetin alfa to darbepoetin alfa in a cohort of unselected hemodialysis patients.

\section{Materials and methods}

We performed an observational, retrospective study of ten dialysis units in the Basque Country, Spain, with data collected from March to May 2011. The main inclusion criteria were patients aged $\geq 18$ years who switched from epoetin alfa to darbepoetin alfa in October 2007 (index date) who had been on hemodialysis for at least 15 months before the index date and remained on hemodialysis for at least 24 months after switching. Only patients with active neoplasia or bleeding were excluded. The study was conducted in accordance with the Helsinki Declaration and the guidelines for Good Clinical Practice. The study protocol was approved by the ethics committee in each participating center. Institutional review board/ethics committee approval was obtained for experimental investigation on human subjects.

The date of switch was considered the index date (Month 0). The conversion rate was left to the discretion of each nephrologist. Both ESAs were administered intravenously using pre-filled syringes. The administration frequency of epoetin alfa was 2-3 times/week and darbepoetin alfa was administered once or twice weekly (two times/week for doses $>80 \mu \mathrm{g} /$ week). Hb was measured monthly, and the ESA dose was adjusted to maintain $\mathrm{Hb}$ within $1.0 \mathrm{~g} / \mathrm{dL}$ of the baseline value. All patients received IV iron $100 \mathrm{mg} / \mathrm{month}$, except if ferritin levels exceeded $600 \mathrm{mg} / \mathrm{dL}$. If ferritin levels decreased to below $200 \mathrm{mg} / \mathrm{dL}$, the dose of IV iron was increased to $100 \mathrm{mg} /$ week. The target for ferritin was $300-500 \mathrm{mg} / \mathrm{dL}$.

The retrospective follow-up period was 36 months: -12 and +24 months relative to the index date. We collected data on $\mathrm{Hb}$, ESA dose, iron dose, weight, bleeding, transfusion of red blood cells, quality of hemodialysis water, serum ferritin, transferrin saturation index (TSI), and C-reactive protein (CRP). Aluminum levels were monitored twice a year. Charlson index was collected annually. Only adverse reactions leading to the discontinuation of darbepoetin alfa were collected.

\section{Statistical analysis}

All ESA doses were converted to IU/kg/week using the 200:1 conversion rate. The erythropoiesis-stimulating agent resistance index (ERI) was calculated by dividing the ESA dose by the $\mathrm{Hb}$ level. ${ }^{22}$

Changes from baseline at post-baseline visits were evaluated using paired $t$-test, Wilcoxon signed-rank test, or McNemar's test as appropriate. Changes in continuous variables over time were evaluated using repeated-measures analysis of variance. Univariate and multivariate linear regression models were used to investigate the influence of several variables on the ERI. Statistical analyses were performed using SAS software (v 9.2; SAS Institute, Cary, NC, USA).

\section{Results}

\section{Patients}

There were 242 prevalent hemodialysis patients at the index date. Of these, 125 were included in the study (67 were excluded due to kidney transplant, 17 due to change to peritoneal dialysis, three due to active neoplasia or bleeding, and 30 due to death). ${ }^{25}$

Patient characteristics are summarized in Table 1. The main comorbidities were hypertension (82.4\%), peripheral vascular disease $(21.6 \%)$, diabetes with end organ damage $(20.8 \%)$, cerebrovascular disease $(17.6 \%)$, chronic pulmonary disease $(13.6 \%)$, arrhythmia $(12.8 \%)$, coronary disease $(12.8 \%)$, myocardial infarction $(10.4 \%)$, and congestive heart failure (10.4\%).

The mean dry weight, Charlson index, and TSI levels remained unchanged after conversion. Ferritin and CRP levels showed a moderate but significant increase over time. The bacterial content and aluminum levels in the water for hemodialysis decreased (Table 2).

\section{$\mathrm{Hb}$ levels over time}

No significant changes in mean and median monthly values of $\mathrm{Hb}$ were observed through the follow-up period 
Table I Population characteristics at the time of switch from epoetin alfa to darbepoetin alfa

\begin{tabular}{ll}
\hline Characteristic & $\begin{array}{l}\text { Patients on } \\
\text { hemodialysis } \\
(\mathbf{n}=125)\end{array}$ \\
\hline Age (years), mean (SD) & $70.4(13.4)$ \\
$\quad$ Range & $27.3-106.7$ \\
Male, \% & 59.7 \\
Dry weight (kg), mean (SD) & $66.6(15.3)$ \\
Range & $40.0-119.5$ \\
Time since CKD diagnosis (months), median (range) & $68(4-615)$ \\
Time on hemodialysis (months), median (range) & $25(3-305)$ \\
Prior transplantation, \% & 14.0 \\
Charlson index, mean (SD) & $7.5(2.2)$ \\
TSI (\%), mean (SD) & $26.5(10.0)$ \\
Serum ferritin (ng/mL), median (range) & $376(36-1,987)$ \\
CRP (mg/dL), median (range) & $0.6(0.1-17.4)$ \\
Characteristics of water for hemodialysis & \\
Conductivity ( $\mu$ S/cm), mean (SD) & $3.0(1.2)$ \\
Temperature ( $\left.{ }^{\circ} \mathrm{C}\right)$, mean $(S D)$ & $20.3(3.8)$ \\
Bacterial content (CFU/mL), median (range) & $2(0-2)$ \\
Aluminum levels (mg/L), median (range)* & $\mathrm{ND}(\mathrm{ND}-16.5)$
\end{tabular}

Note: *The lowest detection level was I $\mu g / \mathrm{L}$.

Abbreviations: CKD, chronic kidney disease; CRP, C-reactive protein; ND, undetectable; SD, standard deviation; TSI, transferring saturation index.

(mean [SD] 11.9 [1.3] g/dL at Month -12, 12.0 [1.5] at Month 0, 12.0 [1.5] at Month 12, 12.0 [1.7] at Month 24, $P=0.409$; Figure 1). Only a slight, nonsignificant increase in mean $\mathrm{Hb}$ levels was observed within the first 3 months after the switch (12.3 [1.4] g/dL at Month 3), which quickly returned to prior levels $(12.1[1.6] \mathrm{g} / \mathrm{dL}$ at Month 4 , $11.9[1.4] \mathrm{g} / \mathrm{dL}$ at Month 6) after minor dose adjustments during the first 2 months of darbepoetin alfa (Figure 2).

Patients were on target levels (10-12 g/dL) for a mean (SD) of 4 (3) months with epoetin alfa and 8 (5) months with darbepoetin alfa, which represents $42.6 \%$ (25.2) and $44.2 \%(21.0)$ of the time, respectively $(P=0.616)$. The coef-

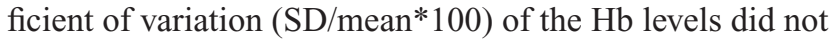

change between the two periods: $11.4 \%$ (95\% confidence interval [CI] 10.8\%-12.0\%) with epoetin alfa; $11.9 \%(95 \%$ CI 11.4\%-12.4\%) with darbepoetin alfa.

No significant changes over time were observed in the number of bleedings or transfusions (data not shown). The percentage of patients suffering a bleeding episode or requiring a blood transfusion was $<1 \%$ in all months.

\section{ESA doses over time}

The ESA dose with epoetin alfa did not show significant variation in the year prior to the switch (annual mean of 174.7 [88.7] IU/kg/week [54.1 (29.8) $\mu \mathrm{g} /$ week]; Figure 2 and Table 3). After conversion, the ESA dose decreased abruptly and significantly $(P<0.0001)$, and, from then on, remained unchanged. Between Months 0 and 12, the mean dose was 95.7 (43.4) IU/kg/week (23.3 [12.5] $\mu \mathrm{g} /$ week). A slight but nonsignificant additional decrease was observed during the second year (mean 91.4 [42.7] IU/kg/week; Table 3). The conversion rate at baseline for the overall group was 332:1.

\section{Resistance index}

The ERI decreased from an annual mean of 15.1 (8.5) IU/kg/week/g/dL with epoetin alfa to 8.1 (3.9) during the first year and 7.9 (4.0) during the second year with darbepoetin alfa (Table 3 and Figure 3 ).

No significant relationship with the ERI was observed for iron dose, quality of hemodialysis water, or CRP levels (data not shown). The Charlson index was the only variable significantly associated with ERI $(P=0.007)$, independently from the type of ESA used.

\section{Results according to baseline ESA dose}

There were significant differences in the reduction of ESA dose between subgroups defined by their baseline dose:

Table 2 Changes in patient characteristics and hemodialysis water over time

\begin{tabular}{|c|c|c|c|c|}
\hline \multirow[t]{2}{*}{ Characteristic } & \multirow[t]{2}{*}{ Epoetin alfa } & \multicolumn{3}{|c|}{ Darbepoetin alfa } \\
\hline & & First year & Second year & P-value \\
\hline Dry weight (kg), mean (SD) & $66.5 \pm 15.1$ & $65.8 \pm 14.6$ & $64.6 \pm 14.2$ & 0.609 \\
\hline Charlson index, mean (SD) & $7.4(2.3)$ & $7.5(2.4)$ & $7.3(2.5)$ & 0.791 \\
\hline Serum ferritin (ng/mL), median (QI, Q3) & $314(199,467)$ & $346(220,494)$ & $372(268,593)$ & 0.038 \\
\hline TSI (\%), mean (SD) & $28.7 \pm 13.0$ & $26.8 \pm 9.6$ & $26.5 \pm 10.0$ & 0.710 \\
\hline CRP (mg/dL), median (QI, Q3) & $0.5(0.2,1.6)$ & $0.9(0.3,3.4)$ & I.5 $(0.5,2.8)$ & 0.025 \\
\hline \multicolumn{5}{|l|}{ Characteristics of water for hemodialysis } \\
\hline Conductivity $(\mu \mathrm{S} / \mathrm{cm})$, mean $(\mathrm{SD})$ & $3.4 \pm 2.0$ & $2.8 \pm 2.7$ & $2.4 \pm 0.98$ & 0.439 \\
\hline Bacterial content (CFU/mL), median (QI, Q3) & $7(0,7)$ & $0(0,0)$ & $I(0, I)$ & $<0.001$ \\
\hline Aluminum levels (mg/L), median (QI, Q3)* & ND (ND, 6.4) & ND (ND, ND) & ND (ND, ND) & 0.003 \\
\hline
\end{tabular}

Note: *The lowest detection level was I $\mu \mathrm{g} / \mathrm{L}$.

Abbreviations: QI, 25th percentile; Q3, 75th percentile; CRP, C-reactive protein; ND, undetectable; SD, standard deviation; TSI, transferring saturation index. 


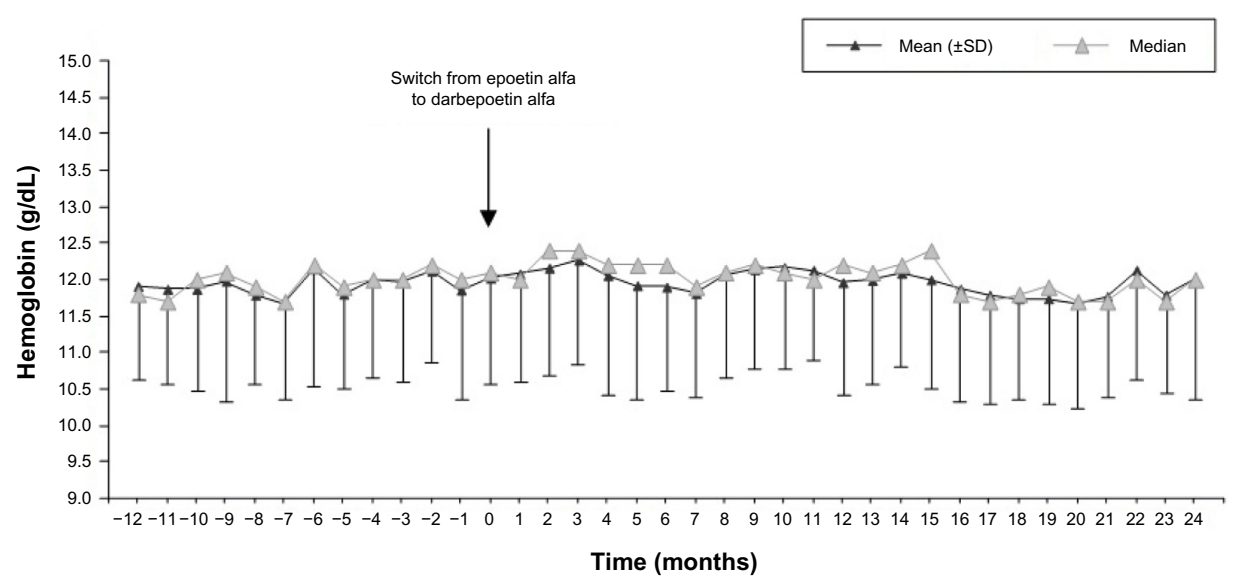

Figure I Changes in hemoglobin levels over time.

Abbreviation: SD, standard deviation.

patients requiring high doses had a greater reduction than patients on medium or low doses (Table 3). The resulting conversion rate was 291:1 for patients on low doses of epoetin alfa ( $\leq 200 \mathrm{IU} / \mathrm{kg} /$ week) and 354:1 for patients requiring doses $>200 \mathrm{IU} / \mathrm{kg} /$ week.

\section{Safety}

There were no discontinuations of darbepoetin alfa due to adverse reactions during the follow-up period.

\section{Discussion}

The present study analyzed the switch from epoetin alfa to darbepoetin alfa in hemodialysis patients. After the switch, the mean ESA dose decreased by $65 \%$, and this reduction was maintained during the subsequent 2 years, without noticeable changes in $\mathrm{Hb}$ levels. Thus, an approximately double efficiency of darbepoetin alfa treatment was observed.
Further, the median values of ESA dose and ERI were much closer to the mean values after the switch. These findings support that there are more "resistant" patients with epoetin alfa, ${ }^{17}$ in whom the conversion rate would be even higher than 350:1.

Our results are consistent with those from randomized and controlled trials, ${ }^{3,26}$ however, the dose reduction was higher in our study, which could be related to the higher proportion of individuals requiring high ESA doses. In prior studies, there was a gradual reduction in the dose of ESA in the first year after conversion due to progressive dose adjustments in response to $\mathrm{Hb}$ levels above targets. In our experience, using a conversion rate of about 330:1, we achieved the early stabilization of $\mathrm{Hb}$ and dose of darbepoetin alfa.

The quality of water for hemodialysis improved during the study, from baseline values fulfilling requirements of "pure water" to final values close to those for

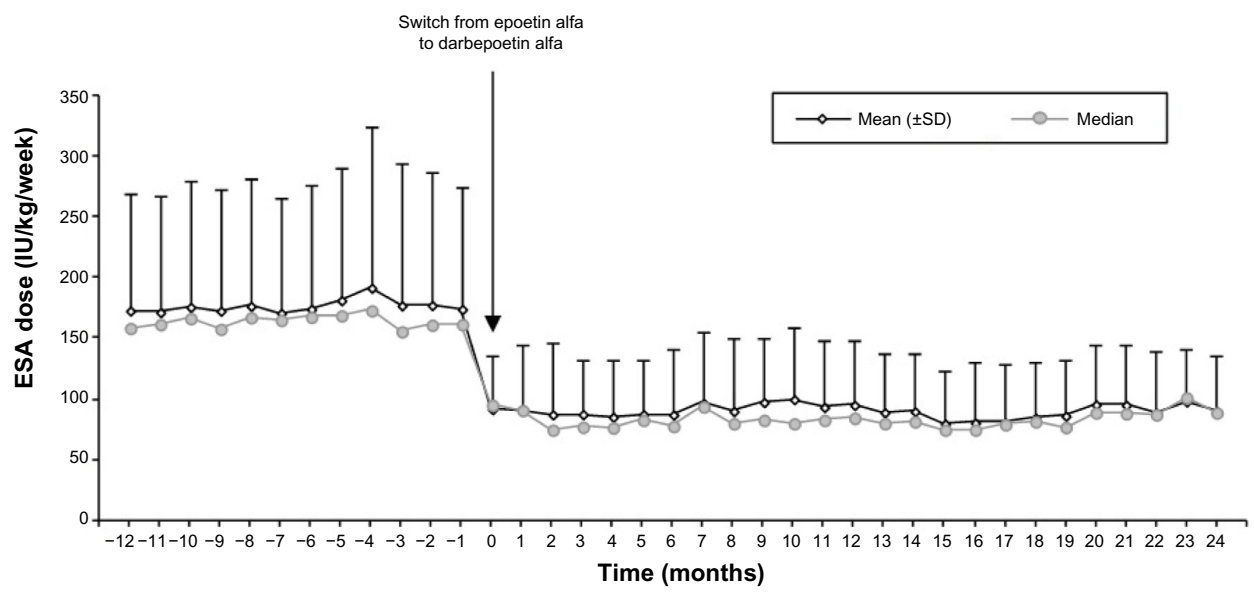

Figure 2 Changes in erythropoiesis-stimulating agent (ESA) dose over time.

Note: Darbepoetin doses were converted at a 1:200 conversion rate.

Abbreviation: SD, standard deviation. 
Table 3 Absolute and relative changes in erythropoiesis-stimulating agent (ESA) dose and erythropoiesis-stimulating agent resistance index (ERI)

\begin{tabular}{|c|c|c|c|c|}
\hline \multirow[t]{2}{*}{ Parameter } & \multicolumn{4}{|c|}{ Dose of epoetin alfa at conversion ${ }^{a}$} \\
\hline & $\begin{array}{l}\text { Low } \\
(<150 \mathrm{IU} / \mathrm{kg} / \text { week }) \\
(\mathrm{n}=50)\end{array}$ & $\begin{array}{l}\text { Intermediate } \\
(150-200 \mathrm{IU} / \mathrm{kg} / \text { week }) \\
(\mathrm{n}=33)\end{array}$ & $\begin{array}{l}\text { High } \\
(>200 \mathrm{IU} / \mathrm{kg} / \text { week }) \\
(\mathrm{n}=4 \mathrm{I})\end{array}$ & $\begin{array}{l}\text { Total } \\
(n=\mid 25)\end{array}$ \\
\hline \multicolumn{5}{|c|}{ ESA dose (IU/kg/week), mean (SD) } \\
\hline Epoetin alfa ${ }^{\mathrm{b}}$ & $93.0(33.6)$ & $175.5(14.4)$ & $273.6(65.3)$ & I $74.7(88.7)$ \\
\hline \multicolumn{5}{|l|}{ Darbepoetin alfa } \\
\hline First year & $67.1(36.8)$ & II $8.2(30.1)$ & II8.5 (37.8) & $95.7(43.4)$ \\
\hline Second year & $69.7(34.4)$ & $103.3(35.8)$ & II4.I (45.8) & $91.4(42.7)$ \\
\hline \multicolumn{5}{|c|}{ ESA dose reduction $(\%)$, mean $(S D)^{c}$} \\
\hline First year & $47.9(18.2)$ & $66.7(17.4)$ & $76.3(36.9)$ & $65.5(30.2)$ \\
\hline Second year & $46.0(21.4)$ & $58.3(20.2)$ & $79.8(32.7)$ & $64.4(30.2)$ \\
\hline \multicolumn{5}{|c|}{ ERI (IU/kg/week/g/dL), mean (SD) } \\
\hline Epoetin alfa ${ }^{\mathrm{b}}$ & $7.6(2.9)$ & I5.I (I.9) & $24.4(7.3)$ & I5.I (8.5) \\
\hline \multicolumn{5}{|l|}{ Darbepoetin alfa } \\
\hline First year & $5.5(3.1)$ & $10.0(2.8)$ & $10.3(3.5)$ & $8.1(3.9)$ \\
\hline Second year & $5.9(3.1)$ & $9.4(3.8)$ & $9.7(4.2)$ & $7.9(4.0)$ \\
\hline \multicolumn{5}{|c|}{ ERI reduction $(\%)$, mean $(S D)^{c}$} \\
\hline First year & $48.6(19.0)$ & $67.8(19.5)$ & $77.4(37.8)$ & $66.3(31.2)$ \\
\hline Second year & $45.2(22.2)$ & $61.3(23.1)$ & $81.6(33.6)$ & $65.8(31.7)$ \\
\hline
\end{tabular}

Notes: ${ }^{\mathrm{a} N o t}$ available in one patient; ${ }^{\mathrm{b}} \mathrm{mean}$ dose during the year before conversion; ${ }^{c}$ mean of individual percent differences, calculated by dividing the difference between the mean darbepoetin alfa dose and the mean epoetin alfa dose by the mean epoetin alfa dose.

Abbreviations: SD, standard deviation; IU, international units.

"ultrapure water". ${ }^{27,28}$ A good hemodialysis water quality can decrease the ERI. ${ }^{29-31}$ However, the bacterial and aluminum contents with epoetin alfa were already very low relative to the maximum levels allowed for pure water $(<100 \mathrm{CFU} / \mathrm{mL}$ and $<10 \mu \mathrm{g} / \mathrm{L}$, respectively). ${ }^{27,28}$ Also, we did not observe any trend toward improvement in inflammatory parameters (CRP and ferritin levels).

In our population, the conversion rate was higher in patients with relative erythropoietin resistance. These results differ from an Italian study that found the same rate irrespective of the previous dosage of epoetin alfa. ${ }^{32}$ However, these results are similar to those reported by Bock et al: from a conversion factor of around 200:1 in patients using lower doses $(<5,000 \mathrm{IU} /$ week $)$ to more than $300: 1$ at doses of $>10,000 \mathrm{IU} /$ week. ${ }^{23}$ In that study, only $49 \%$ of patients used IV epoetin alfa. An explanation for the differences between the conversion factors at different doses was proposed by Nissenson, ${ }^{17}$ who suggested that epoetin loses some efficacy at high doses. This effect would be related to the use of epoetin in weekly or less frequent schedules. ${ }^{33}$

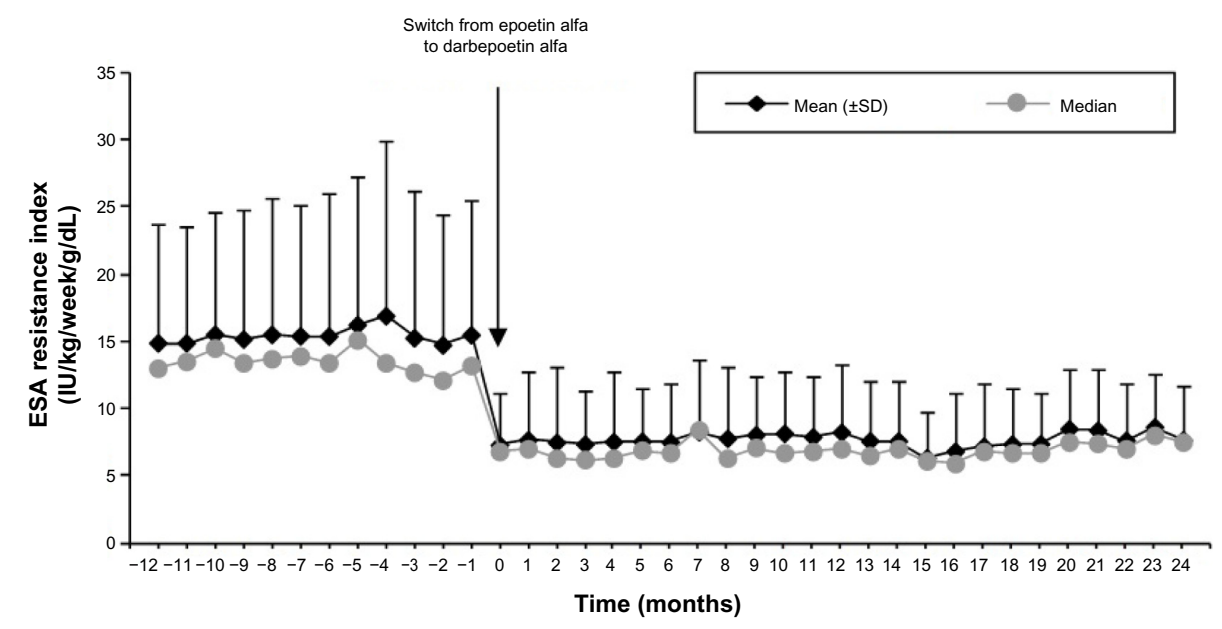

Figure 3 Changes in erythropoiesis-stimulating agent (ESA) resistance index over time. Abbreviation: SD, standard deviation. 
Our study design did not allow for the detailed analysis of within-subject variability. The monthly stability of $\mathrm{Hb}$ levels was comparable, and achieved a mean of 8 months during the 2 years of treatment with darbepoetin alfa. This also raises the possibility of reducing the frequency of $\mathrm{Hb}$ checks. Hb stability was accompanied by an increased ESA dose stability.

Regarding between-subject variability, we did not find any difference in the coefficient of variation of $\mathrm{Hb}$ levels between epoetin alfa and darbepoetin alfa, in line with prior publications that suggest that this type of variability is due to intrinsic factors associated with the disease and its comorbidities. ${ }^{34}$

The main limitation of the study is the fact that data were retrospectively collected. We excluded from the present analysis around $50 \%$ of all prevalent hemodialysis patients. ${ }^{25}$ Although there is a possible bias due to the inclusion of survivors, the exclusion of $30 \%$ of the more stable patients due to transplantation should compensate for this. Thus, we think that our cohort can be regarded as representative of hemodialysis patients receiving ESAs.

\section{Conclusion}

In patients on hemodialysis receiving ESAs, conversion from epoetin alfa to darbepoetin alfa was associated with an approximate and persistent $65 \%$ reduction of the required dose. To maintain $\mathrm{Hb}$ stability, a conversion rate of 300:1 seems to be appropriate for most patients receiving low doses of epoetin alfa ( $\leq 200 \mathrm{IU} / \mathrm{kg} /$ week), while $350: 1$ would be better for patients on higher doses.

\section{Acknowledgments}

Writing assistance was provided by Dr Neus Valveny from Trial Form Support. The authors wish to acknowledge Amgen SA for the financial support of this study.

\section{Disclosure}

The conclusions, interpretations, and opinions expressed herein are those of the authors. This study was financially supported by Amgen. The authors report no other conflicts of interest in this work.

\section{References}

1. Macdougall IC. Optimizing the use of erythropoietic agents pharmacokinetic and pharmacodynamic considerations. Nephrol Dial Transplant. 2002;17 Suppl 5:66-70.

2. Locatelli F, Aljama P, Bárány P, et al; European Best Practice Guidelines Working Group. Revised European best practice guidelines for the management of anaemia in patients with chronic renal failure. Nephrol Dial Transplant. 2004;19 Suppl 2:ii1-ii47.
3. Nissenson AR, Swan SK, Lindberg JS, et al. Randomized, controlled trial of darbepoetin alfa for the treatment of anemia in hemodialysis patients. Am J Kidney Dis. 2002;40(1):110-118.

4. Fishbane S. The role of erythropoiesis-stimulating agents in the treatment of anemia. Am J Manag Care. 2010;16 Suppl Issues: S67-S73.

5. McGowan T, Vaccaro NM, Beaver JS, Massarella J, Wolfson M. Pharmacokinetic and pharmacodynamic profiles of extended dosing of epoetin alfa in anemic patients who have chronic kidney disease and are not on dialysis. Clin J Am Soc Nephrol. 2008;3(4): 1006-1014.

6. Pergola PE, Gartenberg G, Fu M, Wolfson M, Rao S, Bowers P. A randomized controlled study of weekly and biweekly dosing of epoetin alfa in CKD Patients with anemia. Clin J Am Soc Nephrol. 2009;4(11):1731-1740.

7. Dordal MS, Wang FF, Goldwasser E. The role of carbohydrate in erythropoietin action. Endocrinology. 1985;116(6):2293-2299.

8. Egrie JC, Browne JK. Development and characterization of novel erythropoiesis stimulating protein (NESP). Nephrol Dial Transplant. 2001;16 Suppl 3:3-13.

9. Joy MS. Darbepoetin alfa: a novel erythropoiesis-stimulating protein. Ann Pharmacother. 2002;36(7-8):1183-1192.

10. Macdougall IC, Gray SJ, Elston O, et al. Pharmacokinetics of novel erythropoiesis stimulating protein compared with epoetin alfa in dialysis patients. JAm Soc Nephrol. 1999;10(11):2392-2395.

11. Macdougall IC. Darbepoetin alfa: a new therapeutic agent for renal anemia. Kidney Int Suppl. 2002;(80):55-61.

12. Aljama P, Bommer J, Canaud B, et al; NESP Usage Guidelines Group. Practical guidelines for the use of NESP in treating renal anaemia. Nephrol Dial Transplant. 2001;16 Suppl 3:22-28.

13. Hudson JQ, Sameri RM. Darbepoetin alfa, a new therapy for the management of anemia of chronic kidney disease. Pharmacotherapy. 2002;22(9 Pt 2):141S-149S.

14. Locatelli F, Olivares J, Walker R, et al; European/Australian NESP 980202 Study Group. Novel erythropoiesis stimulating protein for treatment of anemia in chronic renal insufficiency. Kidney Int. 2001;60(2):741-747.

15. Ibbotson T, Goa KL. Darbepoetin alfa. Drugs. 2001;61(14):2097-2104; discussion 2105-2106.

16. Macdougall IC, Roberts DE, Coles GA, Williams JD. Clinical pharmacokinetics of epoetin (recombinant human erythropoietin). Clin Pharmacokinet. 1991;20(2):99-113.

17. Nissenson AR. Dosing darbepoetin alfa. Am J Kidney Dis. 2002; 40(4):872.

18. Barnett AL, Crémieux PY. Dose conversion from epoetin alfa to darbepoetin alfa for patients with chronic kidney disease receiving hemodialysis. Pharmacotherapy. 2003;23(5):690-693; discussion 693-694.

19. Deray G. Once-weekly erythropoietic therapy: is there a difference between the available preparations? Nephrol Dial Transplant. 2003;18(11):2455-2456.

20. Jacobs C, Frei D, Perkins AC. Results of the European Survey on Anaemia Management 2003 (ESAM 2003): current status of anaemia management in dialysis patients, factors affecting epoetin dosage and changes in anaemia management over the last 5 years. Nephrol Dial Transplant. 2005;20 Suppl 3:iii3-iii24.

21. Locatelli F, Canaud B, Giacardy F, Martin-Malo A, Baker N, Wilson J. Treatment of anaemia in dialysis patients with unit dosing of darbepoetin alfa at a reduced dose frequency relative to recombinant human erythropoietin (rHuEpo). Nephrol Dial Transplant. 2003;18(2): 362-369.

22. Molina M, García Hernández MA, Navarro MJ, De Gracia MC, Ortuño T. Estudio comparativo sobre el tratamiento de la anemia renal en el paciente en hemodialisis: cambio de via de administracion de epoetina alfa frente a conversion a darbepoetina [Change of EPO treatment from subcutaneous epoetin to intravenous epoetin or darbepoetin alpha]. Nefrologia. 2004;24(6):564-571. Spanish. 
23. Bock HA, Hirt-Minkowski P, Brünisholz M, Keusch G, Rey S, von Albertini B; Swiss EFIXNES trial investigators. Darbepoetin alpha in lower-than-equimolar doses maintains haemoglobin levels in stable haemodialysis patients converting from epoetin alpha/beta. Nephrol Dial Transplant. 2008;23(1):301-308.

24. Molina M, Navarro MJ, de Gracia C, Alvarez G, de Alarcon R, Garcia MA. Change in darbepoetin alfa administration schedule affects erythropoiesis-stimulating agent resistance in patients with chronic kidney disease receiving hemodialysis. Ren Fail. 2008;30(8):778-783.

25. Consejería de Sanidad del Gobierno vasco. Unidad de información sobre pacientes renales de la CAPV 2011, UNIPAR, CAPV 2011. [Health Service of the Basque Country Government. Information unit about renal patients from the Basque Country Authonomous Community 2011 , UNIPAR, CAPV 2011]. Publisher Servicio Central de Publicaciones del Gobierno Vasco. Vitoria-Gasteiz, Spain. 2012. Available from: http:// www.osakidetza.euskadi.net/r85-pkpubl02/es/contenidos/informacion/ osk_publicaciones/es_publi/memorias.html. Accessed June 3, 2014.

26. Molina M, García Hernández MA, Navarro MJ, Pérez Silva F, Cacho M, De Gracia MC. Tratamiento de la anemia renal con administracion una vez cada dos semanas de darbepoetina alfa en pacientes con insuficiencia renal cronica predialisis previamente tratados con epoetina alfa [Treatment of renal anemia with darbepoetin alfa administered once every other week in predialysis patients with chronic kidney disease and previously treated with epoetin alfa]. Nefrologia. 2004;24(1):54-59. Spanish.

27. EBPG Working Group. European best practice guidelines for haemodialysis (Part 1). Section IV.1 Water treatment system. Nephrol Dial Transplant. 2002;17(Suppl 7):45-62.
28. Pérez García R, González Parra E, Ceballos F, et al; Spanish Society of Nephrology. Guías de gestión de calidad del líquido de diálisis (LD) [Guidelines for quality management of dialysis solutions]. Nefrologia. 2004;24 Suppl 2:1-42. Spanish.

29. Schiffl H, Lang SM, Fischer R. Ultrapure dialysis fluid slows loss of residual renal function in new dialysis patients. Nephrol Dial Transplant. 2002;17(10):1814-1818.

30. Furuya R, Kumagai H, Takahashi M, Sano K, Hishida A. Ultrapure dialysate reduces plasma levels of beta2-microglobulin and pentosidine in hemodialysis patients. Blood Purif. 2005;23(4):311-316.

31. Molina M, Navarro MJ, Palacios ME, et al. Importancia del liquido de dialisis ultrapuro en la respuesta al tratamiento de la anemia renal con darbepoetina en el paciente en hemodialisis [Importance of ultrapure dialysis liquid in response to the treatment of renal anaemia with darbepoetin in patients receiving haemodialysis]. Nefrologia. 2007;27(2):196-201. Spanish.

32. Icardi A, Sacco P, Salvatore F, Romano U. Long-term intravenous epoetin-alpha/darbepoetin-alpha ratio in iron-replete hemodialysis patients. J Nephrol. 2007;20(1):73-79.

33. Elliott S, Pham E, Macdougall IC. Erythropoietins: a common mechanism of action. Exp Hematol. 2008;36(12):1573-1584.

34. Pérez-Ruixo JJ, Cucala-Ramos M, García-Gonzalo E, Del Val Romero B, Valveny N. Between subjects variability in haemoglobin and dose are not associated with the erythropoiesis-stimulating agent used to treat anaemia in dialysis: a meta-analysis. $\mathrm{Br} J$ Clin Pharmacol. $2013 ; 75(1): 15-25$

\section{Publish your work in this journal}

The International Journal of Nephrology and Renovascular Disease is an international, peer-reviewed open-access journal focusing on the pathophysiology of the kidney and vascular supply. Epidemiology, screening, diagnosis, and treatment interventions are covered as well as basic science, biochemical and immunological studies. The journal welcomes

\section{Dovepress}

original research, clinical studies, reviews \& evaluations, expert opinion and commentary, case reports and extended reports. The manuscript management system is completely online and includes a very quick and fair peerreview system, which is all easy to use. Visit http://www.dovepress.com/ testimonials.php to read real quotes from published authors. 